\title{
The Integration of Prince Antasari's Character Values into Indonesian Civics Education Learning
}

\author{
Dian Agus Ruchliyadi, Sapriya Sapriya, Kokom Komalasari, Rahmat Rahmat \\ Department of Civic Education \\ Universitas Pendidikan Indonesia \\ Bandung, Indonesia \\ drdianagus@gmail.com, ksapriya@yahoo.com, komsari30@yahoo.co.id,rahmat@upi.edu
}

\begin{abstract}
This study aims to examine and organize the integration of character values from the life history of Prince Antasari's to the Civic Education. This qualitative research was taken place in South Kalimantan Indonesia. Data collection was done through documentation and interview studies, while data validation was conducted using source and method triangulations. Data analysis was done through data reduction, data presentation, and drawing the conclusion. Prince Antasari is a national hero of Indonesia also the leader of Banjar Sultanate that fought with the Dutch colonialism in the war of Banjar at 1859-1905. The result of research showed that the biography and the character values of Prince Antasari's life, that are monotheism which affirms God, hospitable, have a sharp view, permanence and determination, not afraid and not surprised at all the events that happen, have a firm believe, aspire the true independence, democratic, nationalist, does not like to glorify his offspring, humble to the common people, does not feeling tired and exhausted, really hate colonialism, very relevant to integrate it to the Civic Education which aims to increase students' awareness and insight the status of rights and obligations in the life of society, nation and state.
\end{abstract}

Keywords-character value; civic education learning; integration

\section{INTRODUCTION}

Moral decadence becoming one of the threats to the Indonesian people, because it has implications for the destruction of the nation's character such as delays in the democratic process and the promotion of human rights as well as other influences on human life caused by the negative influence of globalization that has increasingly swept countries in various parts of the world including Indonesia. Branson said that "Globalization and its potential for advancing or inhibiting human right and democracy is more than a subject for debate among academics [1]. This power full force is affecting the lives of individuals no matters where in this earth they live".

The Indonesian Child Protection Commission reported that in 2011-2016 there were 5325 child protection cases which includes drug use cases (narcotics, cigarettes, liquor etc), drug dealers (narcotics, cigarettes, liquor, etc), student brawl, school violence (bullying), online sexual crimes, possession of pornographic (cellphone / video, etc) media, physical violence (persecution, beatings, fights, etc), psychological violence (threats, intimidation, etc), sexual violence (rape, sexual abuse, sodomy / pedophilia, etc), murder, theft, traffic accidents, possession of sharp weapons, kidnapping, abortion and placing children as users and perpetrators of these cases (www.bankdata.kpai.go.id). This reality shows that the problem of moral decadence is very concerning, especially the problems that befall to the young generation.

The phenomenon of moral decadence problems can be said as a process of emoting-minding, spiritualizing, valuing and mental round trip which are defeated by the process of thinking and rationalizing, namely learning based on normative / noble / sacred / religious moral values that are inferior to the theoreticconceptual based learning and the calculation of rationalscientific and / or formal juridical profit and loss [2]. Seeing the current condition of Indonesia's young generation character, through the integration of learning with the historical aspects of the nationality of the younger generation, that is, by integrating the character values of Prince Antasari's life history into learning Civic Education is a pre-emptive attempt as well as planting good character values in an effort to handle moral decadence.

In the history, at first, the Dutch came to Indonesia aiming to trade spices, but in its development, this goal changed from the only to trade, to monopolize the trade, and finally, colonizing Indonesia. The process of colonization by the Dutch began with a slow but gradual process of political expansion until it arrived at the Banjar Sultanate region.

The Banjar War began with an internal dispute over the authority of the Kingdom of Banjar, a power struggles that were mixed by the Dutch as an ally of Prince Nata or Sultan Tahmidullah II (1785-1808) in order to get to the throne and get rid of Prince Amir bin Prince Muhammad Aliudddin (Prince Antasari's grandfather) who was later banished to Ceylon (Sri Lanka) in 1787 as a person entitled to the throne. Thanks to the success of the alliance, an agreement "contract 1787" was signed and later a "contract of 1826" was renewed with the Dutch. Through the contract, the Dutch slowly began to interfere in the sultanate's internal affairs and received compensation a part of the Kingdom of Banjar. The intervened of the Dutch in the internal affairs of the Banjar Sultanate such as regarding the replacement of the Sultan after the death of Sultan Adam, and slowly dominating the political legitimacy of the Banjar Sultanate as well as unilaterally dissolved the Banjar Sultanate on 11 June 1860. This was the background of the outbreak of the Banjar War because of dissatisfaction among various groups and began the resistance against Dutch 
injustice. Prince Antasari emerged as the leader in the resistance of the Banjar War due to his sense of responsibility towards the people and to save the sovereignty of the region from Dutch interference because it had tarnished traditions, religious norms and the joints of people's lives [3], [4], [5]. This research aims to study and organize the integration of the character values from the life history of Prince Antasari's resistance into the Civics Education.

\section{METHOD}

This research was conducted in South KalimantanIndonesia in October-December 2017 using a qualitative approach, an approach that does not use quantification efforts or statistical calculations, but rather emphasizes interpretive studies. This study uses historical materials or biographies that have been made, namely in the form of writings from various parties related to Prince Antasari. The writings can be categorized as document material and these writings will be processed for display in the form of the results of this study.

The literature basic materials used in this study include the writings of Hendraswati entitled Nilai-nilai Kepemimpinan dan Kepahlawanan Prince Antasari dalam Perang Banjar; Sejarah Perkembangan Islam di Banjarmasin dan Peran Kesultanan Banjar written by Noor; Norpikriadi's writings titled Perjalanan Kesultanan Banjar: dari Legitimasi Politik ke Identitas Kultural. The writings were used as literature study material because of the suitability of research studies with substantial content of writing needed in the study.

This study was also supported by participants who were considered to have knowledge, understanding, competence, and experience about the study focus and the research objectives that were made as references, among them are Dr. Bambang Subiyakto, M. Hum., Dr. Syaharuddin, M.A., and Mansyur, S.Pd., M. Hum. and Dr. Heri Porda Nugroho, M.Pd. who are academics of the Banjar historians.

Data collection was done through documentation and interview studies, while data validation was conducted using source and method triangulations. Data analysis in this study was carried out by referring to the steps proposed by Miles and Huberman namely: data reduction, data presentation, and conclusion drawing [6]. These three activities are a series of follow-up data analysis activities.

\section{RESULT}

Gusti Inu Kartapati aka Prince Antasari is a national hero of the Indonesian people and is a fighter who acts as a leader and an icon of the Banjar War which lasted from 1859-1905 in the fight for the interests of the people and eradicate the injustice of the invaders, even his head was valued at 10,000 Golden by the Dutch. Prince Antasari was born in Kayu Tangi Martapura in 1787 which was the son of Prince Masohut bin Prince Amir. $\mathrm{He}$ is known as the leader of the movement and the religious leader. He is a warrior figure who is highly respected and admired by society because of his noble personality. Prince Antasari's character personality became a role model for various groups of people, especially for the people of South Kalimantan-Indonesia.
Prince Antasari's leadership, heroism and struggle were widely recognized by many because he had fought for the interests of the people by upholding the slogan "Haram Manyarah Waja Sampai Ka Puting". The motto that was carried out by Prince Antasari became a very popular slogan and gave a fighting spirit to fight the invaders and became the spirit of the resistance in fighting Dutch colonialism in the event of the Banjar War. The motto also has the power of 'magic' in it thus it becomes an encouragement in the struggle to build themselves towards prosperity.

On March 23, 1968, Prince Antasari was awarded the title of National Hero and Independence by the Directorate of Social Heroism, Ministry of Social Affairs of the Republic of Indonesia through Decree No. 06/TK/1968, for his services and dedication that has fought colonial resistance and fight for independence to incarnate the national unity, and provide benefits for welfare and improve human dignity. Prince Antasari's resistance against invaders was carried out for most of his life. He has a high national spirit.

Prince Antasari died on October 11, 1862 at Pucuk Cahu (Muara Teweh, Central Kalimantan). The services of Prince Antasari's resistance were enshrined in several facilities and infrastructure, institutions or assosiacitions that showed a form of warning and appreciation to Prince Antasari for his services as a valiant fighter in fighting the invaders in the Banjar War. As for the results of reviewing the life history and the resistance of Prince Antasari, fourteen (14) character values have been found. The fourteen-character values are: (1) monotheism imposes God; (2) hospitality; (3) sharp view; (4) permanence and determination; (5) does not afraid of all the events that happen; (6) does not shocked from the events that happen; (7) have a firm believe; (8) aspire the true independence; (9) democrat; (10) nationalist; (11) does not like to glorify his offspring; (12) humble to the common people; (13) does not feeling tired and exhausted; (14) really hate colonialism.

\section{DISCUSSION}

The problem of moral decadence of the young generation must get serious attention from various circles. Developing the national character (national character building) such as through character education and multicultural education in the development of personality and living in the social world are strategic steps in the formation of a golden generation and have been widely recognized and become an important aspect in the framework of maintaining and sustaining the existence as a nation-state in shaping the character of good citizens [7], [8].

The cause of moral decadence is also influenced by situational forces, because situational strength can provide sufficient explanation for observable behavior, behavior that is seen as uninformative of the character or disposition that underlies a person [9], [10]. Pressure due to situational circumstances encourages a person to do an action that violates morals. Moral behavior is basically driven by emotional impulsivity, like madness that is seen as a cause of behavior that lies outside one's control and produces behavior that does not reflect the underlying character of a person, because actions or behaviors that bring harm to others who are innocent or 
violate the rules of justice generally have prescriptive views as moral offenses [11], [12].

Today, globalization has brought people to a revolution that produces cultural changes that must be faced as part of the world's citizens [8]. In dealing with the influence of these cultural changes, especially those with negative impacts can be handled with character education, one of which is through Civics. Facing this globalization era, Civics should develop the civic competencies which include aspects of civic knowledge, civic skill, and civic disposition so that it can foster a good character of citizens [1].

Character education is the first mission in the national development from eight missions that must be realized in order to realize the vision of national development as contained in the Annex to the Law of the Republic of Indonesia Number 17 of 2007 concerning the National Long-Term Development Plan for 2005-2025 which states that the realization of Indonesian human resources with the character of smart, tough, competitive, noble, moral based on the philosophy of Pancasila which is characterized by the character and behavior of human beings and Indonesian people who are religious, believing, and fear God Almighty, virtuous, tolerant of diversity, collaborate, patriotic, dynamic and science and technology oriented. The characters contained in the vision of national development can be elaborated and developed from the values of the character of Prince Antasari, because, substantially, the character values of Prince Antasari have harmony with the character values that are to be realized in the context of the character education mission in the vision of national development. This shows that the character values of both are very relevant to be integrated in Civics learning.

Civic Education is the right vehicle in the process of character education as "national character building" and in strengthening the civic virtue of citizens so that they can respond wisely and judiciously in exercising their rights and obligations as citizens in the life of the nation and state, because as an education program, Civic has a mission sacre with idealism to educate the nation's life based on the formation of national character and civilization so that the people can become a democratic and responsible human being both philosophically, socio-politically and psych pedagogically [13], [14].

Integrating character values into learning is the introduction of values, facilitation gained awareness of the importance of values and internalization of values into the daily behavior of students through the learning process that takes place both inside and outside the classroom in all subjects [15]. The integration of character education through this learning process is pursued by the paradigm that all teachers are character educators. All subjects are also assumed to have a mission in shaping the noble character of the students. Integration of character education in the learning process in schools is carried out starting from the planning, implementation, to learning evaluation stages in all subjects [16]. The integration of the character values of the life history of the resistance of Prince Antasari into the process of learning Civics Education aims to increase students' awareness and insight on the status of their rights and obligations in social life, nation and state and improve the quality of themselves as a human being.

At the learning implementation plan stage (RPP) character values are seen in the core competencies. Core competencies are designed in four interrelated groups which are related to religious attitudes (core competence 1), social attitudes (core competency 2), knowledge (core competency 3), and application of knowledge (core competency 4). The four groups become the reference of basic competencies and must be developed in each learning event interactively. Competencies relating to religious and social attitudes are developed indirectly (indirect teaching), namely when students learn about knowledge (group 3 competence) and application of knowledge (group 4 core competencies) [17].

Through the integration of the values of the characters, students can learn, take lessons from character, from the biography of a historical figure about the personality of the character [18]. Thus, the life history and struggle of Prince Antasari with the 14-character values contained in it can be a source or material that is relevant for the learning of Civics Education in the development of character formation.

\section{CONCLUSION}

Research on the life history and struggle of Prince Antasari as this object has found character values that are relevant to Civics, and can be used as material or sources of learning in character education through the Civics learning process. The integration of character values aims to increase students' awareness and insight on the status of their rights and obligations in the life of society, nation and state and to improve the quality of themselves as human beings.

\section{REFERENCES}

[1] Branson, S. Margaret, The Role of Civic Education: A Forthcoming Education Policy Task Force Position Paper From the Communitarian Network, Calabasas: CCE, 1998.

[2] K. A. Djahiri, Moral and Character Teaching Values and Social Moral Development, Bandung: Lab. Pengajaran PMP FPIPS UPI, 2002.

[3] Hendraswati, "Nilai-Nilai Kepemimpinan dan Kepahlawanan Prince Antasari dalam Perang Banjar,” Jantra, vol. 10, No. 1, pp. 83-90, 2015.

[4] Norpikriadi, Perjalanan Kesultanan Banjar: dari Legitimasi Politik ke Identitas Kultural Naditira Widya, vol. 8, No. 2, Balai Arkeologi Banjarmasin, 2014.

[5] Y. Noor, Sejarah Perkembangan Islam di Bajarmasin dan Peran Kesultanan Banjar (Abad XV-XIX), Al-Banjar, vol. 11, No. 2, 2012, pp 239-267.

[6] M.B. Miles, and A.M. Huberman, Analisis Data Kualitatif, Jakarta: UI Press, 1992.

[7] B. Mulyono, "Reorientasi civic disposition dalam kurikulum Pendidikan Kewarganegaraan sebagai upaya membentuk warga negara yang ideal," Jurnal Civics, vol. 14, No. 2, pp. 218-225, 2017.

[8] E. Malihah, "An ideal Indonesian in an increasingly competitive world: Personal character and values required to realise a projected 2045 'Golden Indonesia'," Citizenship, Social and Economic Education, vol. 14, No. 2, pp. 148-156, 2015.

[9] E. E. Jones, and K. E. Davis, From acts to dispositions: The attribution process in person perception, In L. Berkowitz (Ed.), Advances in experimental social psychology, New York, NY: Academic Press, 1965. 
[10] E. E. Jones, K. E. Davis, and K. J. Gergen, "Role playing variations and their informational value for person perception," Journal of Abnormal and Social Psychology, vol. 63, pp. 302-310, 1961

[11] C. R. Critcher, Y. Inbar, and D. A. Pizarro, "How Quick Decisions Illuminate Moral Character," Social Psychological and Personality Science, vol. 4, No. 3, pp. 308-315, 2012.

[12] J. Graham, J. Haidt, and B. Nosek, "Liberals and conservatives use different sets of moral foundations," Journal of Personality and Social Psychology, vol. 96, pp. 1029-1046, 2009.

[13] Y.G. Malatuny, and Rahmat, "Pembelajaran Civic Education dalam Mengembangkan Civic Disposition," Jurnal Pedagogika dan Dinamika Pendidikan, vol. 6, No. 1, pp 56-68, 2017.
[14] U.S. Winataputra, dan D. Budimansyah, Pendidikan Kewarganegaraan dalam Perspektif Internasional: Konteks, Teori dan Profil Pembelajaran, Bandung: Widja Aksara Press, 2012.

[15] Kemendiknas, Pengembangan Pendidikan Budaya dan Karakter Bangsa Pedoman Sekolah, Jakarta: Badan Penelitian dan Pengembangan, Pusat Kurikulum, 2010.

[16] Mulyasa, Manajemen Pendidikan Karakter, Jakarta: Bumi Aksara, 2014.

[17] Kemendikbu, "Kompetensi Dasar untuk Sekolah Dasar/Madrasah Ibtidaiyah kurikulum 2013", Retreived from www.kemdiknas.go.id. Accesed 18 Januari 2016.

[18] T. Lickona, Character Matters: How to Help Our Children Develop Good Jugdement, Integrity, and Other Essential Virtues,New York: Simon and Schuster, 2004. 